\title{
ASSESSMENT OF THE IMPACT OF INDUSTRIAL DEVELOPMENT AT THE COAST OF LÉVRIER BAY THROUGH THE SPATIO-TEMPORAL STUDY OF METALLIC CONTAMINANTS (CD, PB, CU, ZN AND HG) IN SURFACE SEDIMENTS
}

\author{
M'Beirika AHMED SALEM CHEIKH ${ }^{1,3}$, Mohamed Salem EL MAHMOUD-HAMED ${ }^{2}$, \\ Día MAMADOU ${ }^{3}$, Harouna TOUNKARA ${ }^{2}$, Mohamed El Housseine LEGRAA ${ }^{3}$, \\ Mohamed RAMDANI ${ }^{4}$ and Zeinebou SIDOUMOU
}

DOI: $10.21163 / \mathrm{GT} \_2020.152 .13$

\begin{abstract}
:
Lévrier Bay is located at the northern Atlantic Mauritanian coast, between $19^{\circ} 20^{\prime} \mathrm{N}$ and 20 ${ }^{\circ} 40^{\prime} \mathrm{N}$ and between the coast and $17^{\circ} 20 \mathrm{~W}$ in the vicinity of Cap Blanc peninsula. This work aims at contributing to the assessment the impact of industrial development in the Lévrier Bay through the study of the toxicity and the spatio-temporal distribution of trace metals $(\mathrm{Cd}, \mathrm{Pb}, \mathrm{Cu}, \mathrm{Zn}$ and $\mathrm{Hg})$ in surface sediments, during the four hydrological seasons. The trace metal concentrations of the sediments are generally heterogeneous and vary according to the metal analyzed and the sampling site according to the order $\mathrm{Zn}>\mathrm{Cu}>\mathrm{Pb}>$ $\mathrm{Cd}>\mathrm{Hg}$. In fact, the present work shows higher average concentrations of metals studied in surface sediments than those found for the same metallic elements in previous recent studies at Lévrier Bay, which may be due to anthropogenic pressure in these areas. , especially since the different sites of the Bay are deprived of any sanitation system. In addition, the levels of these metals in the sediments of Lévrier Bay are below the international standards recommended for the toxicity assessment of sediments.
\end{abstract}

Key-words: Sediment, Trace metals, Industries, Seasons, Lévrier Bay

\section{INTRODUCTION}

The fisheries sector is one of the pillars of Mauritania's economy and the main activities related to this sector are located in the Lévrier Bay. The Lévrier Bay is located at the northern Atlantic Mauritanian coast, between $19^{\circ} 20^{\prime} \mathrm{N}$ and $20^{\circ} 40^{\prime} \mathrm{N}$ and between the coast and $17^{\circ} 20 \mathrm{~W}$ in the vicinity of Cap Blanc peninsula. (Fig.1).In addition, this area includes two natural sites of great ecological importance, notably the Cap Blanc satellite reserve, classified as World Heritage (recognized for its role in protecting the last viable colony of Mediterranean monk seals) and the Baie de l'Etoile, site recognized by IUCN and candidate to be classified Marine Protected Area (IUCN, 2008). This area is characterized by four hydrological seasons. They have been identified in the context of studies carried out in Mauritanian marine waters (Dubrovin et al.1991; Wagne et al.2011; Wagne et al.2013), namely, the cold season (January to May) and the hot season (August to October). These are interspersed by two inter-seasons, hot-cold (from June to July) and cold- hot (from November to December).

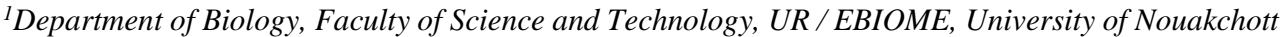
AL Aasriya, Mauritania mbksalem1@yahoo.fr,mintsidoumou@yahoo.fr

${ }^{2}$ National Office for Sanitary Inspection of Fisheries and Aquaculture Products (ONISPA), Mauritania imouh84@yahoo.fr, h_tounkara@yahoo.fr

${ }^{3}$ Mauritanian Institute for Oceanographic and Fisheries Research (IMROP), madou.mr@gmail.com, legraahoussein@yahoo.fr, mbksalem1@yahoo.fr

${ }^{4}$ Institut Scientifique Rabat, Université Mohamed V Agdal, Avenue Ibn Batouta, Maroc, ramdanimed@gmail.com
} 
The Lévrier bay is under heavy human pressure because of the economic activities. Indeed, the installation of fishing companies such as fishmeal and fish oil factories which represent 32 factories in more than 70 establishments for processing fishery products intended for human consumption (WebgateEU2019). These pressures are, among other things, at the origin of several types of industrial discharges at sea, such as 2,388 active canoes (IMROP 2019), the presence of four main ports (fishing, trade, mineral and petroleum), in addition to domestic discharges are all potential sources of chemical pollution (Dartige and OuldDedah1996;Belin and Le Gal2005). These various urban and industrial wastes are directly dumped into the marine environment in the absence of any sanitation system. In addition, Zamel et al. 2010 have shown that 75,632 m3 of wastewater are discharged daily into the bay, including $3 \mathrm{~m} 3$ of oily water and 51,755 tons of solid discharge which constitute a major source of pollution, harmful to the bay environment. In the aquatic and coastal environment, numerous studies have shown that trace metals are used to reveal the level of anthropogenic influence, because they are persistent, toxic and have a tendency to bioaccumulate that which constitutes a risk for biotas and ecosystems (USEPA 2002; Memet 2011; Diop et al. 2012; Liang et al.2013).

In Mauritania, numerous studies on the state of contamination of the Atlantic coasts of Nouadhibou (Lévrier Bay) by trace metals in biological tissues have been carried out, notably in bivalve filter molluscs (Sidoumouet al.1992; Dardige2006; Wagneet al.2013; M'Hamada et al.2014; Legraa et al.2019). For the first time a study using the sediment matrix over two seasons only (cold season and hot season) during 32 months from January 2013 to October 2016 (Legraa et al.2019) has been conducted. For the sake of contributing to the evaluation of the impact of industrial development at the level of the Lévrier Bay, the present study was conducted, to assess the toxicity and the spatiotemporal distribution during the four hydrological seasons in the surface sediment matrix. To give a better visibility of the space-time distribution, we will compare our results with those found by authors cited above.

\section{MATERIALS AND METHODS}

\subsection{Sampling}

Depending on the nature of the industrial activities, eight sites (discharge points) were chosen according to the nature of the discharges from the source of pollution, at the Lévrier Bay (Fig. 1). The different sampling sites were subject to seasonal monitoring and the characteristics of the sampled sites are as follows:

- Bountiya (hereafter BONT): area of agglomeration of fishmeal and fish oil production factories, which generate several types of discharges such as: waste water, organic matter, solid discharges and cooling water, etc.

- Port Artisanal (hereafter EPBR): home port and landing of canoes and coastal vessels intended for artisanal fishing generating the main discharges which may contain oils, fuel, detergents, waste water (untreated) and solid waste.

- Centrale électrique [fr] (Powerplant, hereafter CE): main thermal power station, which supplies electricity to the Nouadhibou city including the discharge of hot and contaminated water.

- Port minéralier [fr] (Mineral port, hereafter PM): main port for loading iron ore.

- $\quad$ SNIM 1 (Port minéralier = Mineral port): tidal balancing area near the mining port

- $\quad$ SNIM2 (Port minéralier = Mineral port): tidal balancing area near the mining port further offshore.

- Cap Blanc coast (hereafter CBC): witness sites (absence of industries).

- Cap Blanc large (hereafter CBL): the tip of Cap Blanc, which is a tidal balancing area.

We carried out 3 sampling sat each site and per hydrological season during the period from June 2016 to December 2017. The offshore sediment sampling was carried out on board of a research boat (Amrigue), using an Eckman type grab whose jaws close automatically, thus collecting the substrate (sediment), over an area of $1,225 \mathrm{~m}^{2}$. In the coastal area, the sediments were collected on a canoe 
board, using an Eckman type grab over an area of $0,225 \mathrm{~m}^{2}$, however, at the sampling sites located on the coast (intertidal area), surface sediments were collected using a PVC cover with $66 \mathrm{~mm}$ in diameter and $50 \mathrm{~cm}$ in length over a depth of $5 \mathrm{~cm}$.

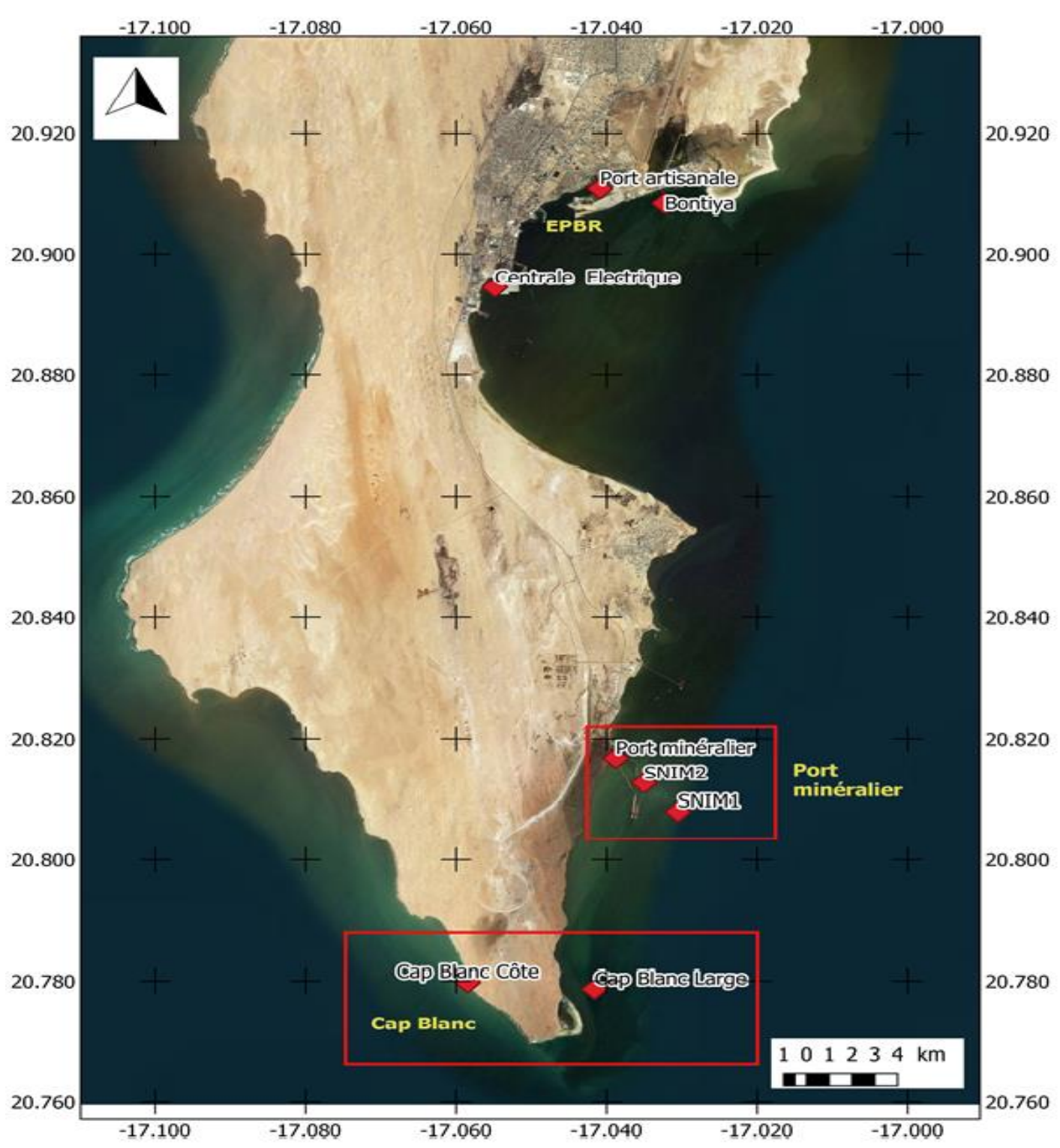

Fig.1. Location of the study area and sampling sites.

\subsection{Sample preparation and analytical procedure}

Samples of $0.5 \mathrm{~g}$ were digested by duplicate, then, were placed in microwave closed-vessels with a mixture (6:2) of ultra-pure nitric acid $67 \%$ and hydrogen peroxide $30 \%$ at room temperature for one hour and then extracted by microwave. Digestion conditions applied in the microwave system were as follows: $3 \mathrm{~min}$ at $250 \mathrm{~W}, 5 \mathrm{~min}$ at $650 \mathrm{~W}, 22 \mathrm{~min}$ at $500 \mathrm{~W}, 5 \mathrm{~min}$ at $0 \mathrm{~W}$ and vent. The digested samples were diluted to $50 \mathrm{~mL}$ with deionized water (Milli-Q quality). 
The analysis of $\mathrm{Pb}, \mathrm{Zn}, \mathrm{Cu}$ and $\mathrm{Cd}$ were conducted using an atomic absorption spectrometer with furnace graphite (LOD of 0.046 for $\mathrm{Pb}$ and $0.004 \mu \mathrm{g} \cdot \mathrm{g}-1$ for other elements), according to the ISO 15586:2003. Hg was analyzed using Direct Mercury Analyzer ( $\mathrm{LOD}=0.003 \mu \mathrm{g} / \mathrm{g}$ ), according to the method "MA.207-Hg 2.0, (Centre d'expertise en analyse environnementale du Québec).

The potential presence of trace metals in the chemicals that were used during the digestion was determined. Blanks were run simultaneously in each batch analysis to authenticate the analytical quality. All of the glassware and plastics were soaked overnight in $10 \%$ (v/v) nitric acid, rinsed with distilled and deionized water and dried before being used. The potential presence of trace metals in the chemicals that were used during the digestion was determined. Blanks were run simultaneously in each batch analysis to authenticate the analytical quality. All of the glassware and plastics were soaked overnight in $10 \%$ (v/v) nitric acid, rinsed with distilled and deionized water and dried before being used.

Samples were mineralized by nitric acid (67\%) mixed with hydrogen peroxide (30\%) and then the extraction was carried out using an Anton- Paar microwave model Multiwave-3000.

Atomic Absorption Spectrometer (AAS, Perkin Elmer AAnalyst 800) and Direct Hg Analyzer (DMA-80, Millstone) equipment was used to analyze the trace metals. The certified standard reference material for sediment samples (BCR 146R) was used, it shows recoveries varied from 93\% to $113 \%$ of certified values (Table 1).

Table 1.

Measured and certified values of metal concentrations $(\mathrm{mg} / \mathrm{kg})$.

\begin{tabular}{|c|c|c|c|c|c|}
\hline & Cd & Pb & Cu & Zn & Hg \\
\hline $\mathrm{n}$ & 4 & 4 & 4 & 4 & 4 \\
\hline Measured value & 18 & 569,7 & 966,7 & 2839,3 & 7,6 \\
\hline certificate value & $18 \pm 0.5$ & $609 \pm 14$ & $838 \pm 16$ & $3060 \pm 60$ & 93 \\
\hline Recovery (\%) & 102 & 94 & 116 & 93 & 90,5 \\
\hline
\end{tabular}

\subsection{Statistical analysis}

All data were imported and statistically processed in the SPAD software (version. 5) and Excel 2016. The trace metal concentrations in the sediments were compared at the different sites in the study area and during the hydrological seasons (Spatio-temporal distribution). The study of variations of intra-site and inter-site, trace metals as well as the correlations study between trace metals (PCA) were carried out.

\section{RESULTS AND DISCUSSION}

The results obtained relate to the variations in trace metals concentrations $(\mathrm{Cd}, \mathrm{Pb}, \mathrm{Cu}, \mathrm{Zn}$ and $\mathrm{Hg}$ ) in the surface sediments of the sampling sites exposed to different industrial and urban discharges and then the results found are presented in Table 2.

Cadmium (Cd) variations were found for the lowest value at $0.00 \mathrm{mg} / \mathrm{kg}$ at the $\mathrm{CE}$, while the largest value $(0.58 \mathrm{mg} / \mathrm{kg})$ was recorded at the CBL offshore. In addition, the average minimum and maximum concentrations recorded for $\mathrm{Cd}$ are respectively: $(0.04 \pm 0.014 \mathrm{mg} / \mathrm{kg}$ and $0.265 \pm 0.078$ $\mathrm{mg} / \mathrm{kg}$ ) at CE and EPBR. The important significant variations of Cd concentrations $(0.04$ to $0.58 \mathrm{mg}$ / kg; 0.07 to $0.42 \mathrm{mg} / \mathrm{kg} ; 0.03$ to $0.39 \mathrm{mg} / \mathrm{kg}$ and 0.14 to $0.38 \mathrm{mg} / \mathrm{kg}$ ) by site are recorded, respectively, at CBL, EPBR, PM and BONT. While the lowest variations of Cd concentrations ( 0.00 to $0.07 \mathrm{mg} / \mathrm{kg}$ and SNIM1 0.08 to $0.2 \mathrm{mg} / \mathrm{kg}$ ) were found in the CE site, we note nevertheless the absence of variation of the Cd concentration values at the SNIM2. 
Table 2.

Concentrations of trace metals (mean \pm Standard deviation: $\mathrm{mg} / \mathrm{kg}$ ) in sediments for the studied sites.

\begin{tabular}{|c|c|c|c|c|c|}
\hline Sites & Cd & Pb & Cu & Zn & Hg \\
\hline EPBR & $0,265 \pm 0,078$ & $5,7 \pm 2,924$ & $11,284 \pm 4,903$ & $47,245 \pm 16,835$ & 0,008 \\
\hline CE & $0,04 \pm 0,014$ & $2,125 \pm 0,880$ & $4,434 \pm 1,028$ & $9,185 \pm 1,939$ & 0 \\
\hline BONT & $0,225 \pm 0,053$ & $1,017 \pm 0,393$ & $3,337 \pm 1,319$ & $15,445 \pm 6,906$ & 0,001 \\
\hline PM & $0,142 \pm 0,084$ & $1,722 \pm 0,719$ & $11 \pm 3,214$ & $5,137 \pm 2,072$ & 0 \\
\hline CBC & $0,11 \pm 0,054$ & $0,555 \pm 0,306$ & $6,505 \pm 4,760$ & $5,105 \pm 0,995$ & 0 \\
\hline SNIM1 & $0,137 \pm 0,030$ & $1,135 \pm 0,401$ & $4,862 \pm 1,180$ & $15,035 \pm 4,131$ & 0 \\
\hline CBL & $0,202 \pm 0,126$ & $0,647 \pm 0,294$ & $4,317 \pm 3,400$ & $5,85 \pm 1,774$ & 0 \\
\hline SNIM2 & $0,147 \pm 0,012$ & $0,637 \pm 0,126$ & $2,775 \pm 0,745$ & $8,397 \pm 3,869$ & 0 \\
\hline
\end{tabular}

According to Bowen (1966) the concentration in natural seawater is around $0.1 \mu \mathrm{g} / \mathrm{l}$ and comes mainly from petrochemical or metallurgical industrial activities (Odin1995). Our results for Cd contain a maximum average concentration $(0.265 \pm 0.07 \mathrm{mg} / \mathrm{kg})$, these results are very close to those in the sediments of Dakar coast $(0.270 \mathrm{mg} / \mathrm{kg})$ reported by Diop et al. 2014. But the maximum average value Cd concentration $(0,130 \pm 0,070)$ found by Legraa et al. (2019) at Etoile bay which is part of the Lévrier bay, could lead us to say that the Cd comes from a source of pollution such as the deposit of industrial and anthropogenic discharges and the current discharge in the EPBR.

Although other sources of the $\mathrm{Cd}$ are not excluded, such as the permanent presence of upwelling in the Cap Blanc area, the results found by (Kaimoussi et al.2000) in the coastal marine sediments of the Atlantic coast of the region of EL Jadida in Morocco $(0.75 \mathrm{mg} / \mathrm{kg}$ ) and those reported by (Belabed et al.2013) in the sediments of the Gulf of Annaba in Algeria displayed Cadmium contents (0.02 to $2.2 \mathrm{mg} / \mathrm{kg}$ ).

The lowest $\mathrm{Pb}$ concentration was found at the $\mathrm{CE}(0.00 \mathrm{mg} / \mathrm{kg})$, while at the EPBR the $\mathrm{Pb}$ displayed its highest value $(12.11 \mathrm{mg} / \mathrm{kg}$ ). Yet the mean minimum and maximum $\mathrm{Pb}$ concentrations $(0.555 \pm 0.306 \mathrm{mg} / \mathrm{kg}$ to $5.7 \pm 2.924 \mathrm{mg} / \mathrm{kg})$ are recorded respectively at the CBL and at EPBR. The highest concentrations of $\mathrm{Pb}(0.00$ to $12.11 \mathrm{mg} / \mathrm{kg} ; 0.00$ to $4.11 \mathrm{mg} / \mathrm{kg}$ and 0.00 to $3.10 \mathrm{mg} / \mathrm{kg})$ are respectively recorded at (EPBR, CE and PM), while the lowest concentration $(0.00$ to $0.82 \mathrm{mg} / \mathrm{kg})$ were found at SNIM2. The high concentrations of $\mathrm{Pb}$ can be mainly due to the port activity through the wide use of lead in fishermen's nets and the high fuel consumption by motor boats as well as the nature of the hull paints of the different boats. Lead concentrations in sediments are not high compared to the threshold for unpolluted sediments which is $30 \mathrm{mg} / \mathrm{Kg}$ (OSPAR, 1997).

The lowest Copper $(\mathrm{Cu})$ concentration $(0.09 \mathrm{mg} / \mathrm{kg})$ was found at $\mathrm{CBL}$, while the highest most concentration $(24.40 \mathrm{mg} / \mathrm{kg})$ was recorded at the EPBR. In addition, the average concentrations of $\mathrm{Cu}$ $(2.775 \pm 0.745 \mathrm{mg} / \mathrm{kg}$ and $11.284 \pm 4.903 \mathrm{mg} / \mathrm{kg})$ were recorded respectively at SNIM 2 and the EPBR site. The significant variations in Cu concentrations $(3.52$ to $24.40 \mathrm{mg} / \mathrm{kg} ; 0.80$ to $20.74 \mathrm{mg} / \mathrm{kg} ; 3.70$ to $19.15 \mathrm{mg} / \mathrm{kg} ; 1.03$ to $6.70 \mathrm{mg} / \mathrm{kg}$ and 2.74 to $6.99 \mathrm{mg} \mathrm{kg}$ ) were recorded respectively at EPBR, $\mathrm{CBC}, \mathrm{PM}, \mathrm{CE}, \mathrm{BONT}$ and SNIM1. The average concentration of $\mathrm{Cu}(11.284 \pm 4.903$ and $11 \pm 3.214$ $\mathrm{mg} / \mathrm{kg}$ ) were respectively recorded at EPBR and PM, indeed, $\mathrm{Cu}$ is considered like an urban pollutant (Pichardetal. 2005), then, these high concentrations can be explained by a high contribution of industrial discharges and urban domestic waste from Nouadhibou city without any sanitation system.

The variations in Zinc ( $\mathrm{Zn}$ ) found for the lowest values at $0.00 \mathrm{mg} / \mathrm{kg}$ at the BONT site and SNIM2, while the most important value at $77.2 \mathrm{mg} / \mathrm{kg}$ was recorded at the EPBR level. In addition, the average concentrations Minimum and Maximum recorded for Zinc are respectively $5.105 \pm 0.995$ $\mathrm{mg} / \mathrm{kg}$ in the two sites (CBC and SNIM2) and $47.245 \pm 16.835 \mathrm{mg} / \mathrm{kg}$ in the EPBR. Although, the average maximum metal concentrations of $\mathrm{Zn}$ at BONT and EPBR do not exceed the guideline values of surface sediments toxicity, they remain higher than those at (CE, PM, SNIM and CB) sites, which can be explained by the pressure due to artisanal canoes and coastal boats at EPBR area and the 
regrouping of fishmeal and fish oil production factories in the BONT area. In fact, these two zones are deprived of any drainage system, in addition to the weak currentology in the Lévrier bay.

The high concentration of $\mathrm{Zn}$ was recorded at EPBR while the lowest concentration was fond at BONT and SNIM2. In addition, the minimum and maximum average $\mathrm{Zn}$ concentrations (4.72 to 77.2 $\mathrm{mg} / \mathrm{kg} ; 00.0$ to $30.20 \mathrm{mg} / \mathrm{kg} ; 2.87$ to $21,30 \mathrm{mg} / \mathrm{kg} ; 0.00$ to $16.30 \mathrm{mg} / \mathrm{kg} ; 4.72$ to $13.2 \mathrm{mg} / \mathrm{kg} ; 0.52$ to $10.6 \mathrm{mg} / \mathrm{kg}$ ) were recorded respectively at the EPBR, BONT, SNIM2, EC and PM.

In the present study, all mercury $(\mathrm{Hg})$ concentrations are below the detection limit $(<0.0058)$ for all sites and during all seasons with the exception of EPBR and BONT during the cold season and the inter hot cold season. The maximum value was recorded at EPBR $(0.03 \mathrm{mg} / \mathrm{kg})$, however this value remains below the standard of $0.5 \mathrm{mg} / \mathrm{kg}$ set by the OSPAR convention (1997) for sediments contaminated by $\mathrm{Hg}$. Lead, coper and Zinc levels in Lévrier Bay are the highest in Mauritania coast. The increase of trace metals concentration in levier Bay environment is caused by the demographic and industry development in Nouadhibou city, which is became a free zone and it known a proliferation of fish industry (Table 3 ).

Table 3.

Comparison of the results of this study with other results from the littoral zone of Mauritania $(\mathrm{mg} / \mathrm{kg})$.

\begin{tabular}{|c|c|c|c|c|c|c|c|}
\hline Site & Cd & $\mathbf{P b}$ & $\mathrm{Cu}$ & $\mathbf{Z n}$ & Hg & Coordinates & $\begin{array}{c}\text { Referen } \\
\text { ces }\end{array}$ \\
\hline EPBR & $0,265 \pm 0,078$ & $5,7 \pm 2,924$ & $11,284 \pm 4,903$ & $47,245 \pm 16,83$ & $0,008 \pm 00$ & $\begin{array}{c}20^{\circ} 54^{\prime} 38.8^{\prime \prime N} . \\
17^{\circ} 02^{\prime} 27.1^{\prime \prime} \mathrm{W}\end{array}$ & \multirow{8}{*}{$\begin{array}{l}\text { Present } \\
\text { study }\end{array}$} \\
\hline $\mathrm{CE}$ & $0,04 \pm 0,014$ & $2,125 \pm 0,880$ & $4,434 \pm 1,028$ & $9,185 \pm 1,939$ & 0 & $\begin{array}{l}20^{\circ} 53^{\prime} 40.0^{\prime \prime} \mathrm{N} . \\
17^{\circ} 03^{\prime} 17.4^{\prime \prime} \mathrm{W}\end{array}$ & \\
\hline BONT & $0,225 \pm 0,053$ & $1,017 \pm 0,393$ & $3,337 \pm 1,319$ & $15,445 \pm 6,906$ & $0,001 \pm 00$ & $\begin{array}{l}20^{\circ} 54^{\prime} 30.1^{\prime \prime N} \\
17^{\circ} 01^{\prime} 56.2^{\prime \prime} \mathrm{W}\end{array}$ & \\
\hline PM & $0,142 \pm 0,084$ & $1,722 \pm 0,719$ & $11 \pm 3,214$ & $5,137 \pm 2,072$ & 0 & $\begin{array}{l}20^{\circ} 49^{\prime} 00.5^{\prime \prime} \mathrm{N} . \\
17^{\circ} 02^{\prime} 19.6^{\prime \prime} \mathrm{W}\end{array}$ & \\
\hline $\mathrm{CBC}$ & $0,11 \pm 0,054$ & $0,555 \pm 0,306$ & $6,505 \pm 4,760$ & $5,105 \pm 0,995$ & 0 & $\begin{array}{c}20^{\circ} 46^{\prime} 47.2^{\prime \prime} \mathrm{N} . \\
17^{\circ} 03^{\prime} 30.4^{\prime \prime} \mathrm{W}\end{array}$ & \\
\hline SNIM1 & $0,137 \pm 0,030$ & $1,135 \pm 0,401$ & $4,862 \pm 1,180$ & $15,035 \pm 4,131$ & 0 & $\begin{array}{l}20^{\circ} 48^{\prime} 28.8^{\prime \prime} \mathrm{N} . \\
17^{\circ} 01^{\prime} 49.8^{\prime \prime} \mathrm{W}\end{array}$ & \\
\hline $\mathrm{CBL}$ & $0,202 \pm 0,126$ & $0,647 \pm 0,294$ & $4,317 \pm 3,400$ & $5,85 \pm 1,774$ & 0 & $\begin{array}{cc}20 & 46.722 \mathrm{~N} . \\
17 & 02.496 \mathrm{~W}\end{array}$ & \\
\hline SNIM2 & $0,147 \pm 0,012$ & $0,637 \pm 0,126$ & $2,775 \pm 0,745$ & $8,397 \pm 3,869$ & & $\begin{array}{l}20^{\circ} 48^{\prime} 45.5^{\prime \prime} \mathrm{N} . \\
17^{\circ} 02^{\prime} 06.0^{\prime \prime} \mathrm{W}\end{array}$ & \\
\hline COMECA & $0,090 \pm 0,018$ & $1,671 \pm 0,534$ & $0,084 \pm 0,003$ & $1.349 \pm 0,011$ & $\begin{array}{c}0,016 \\
\pm 0,002\end{array}$ & $\begin{array}{l}20^{\circ} 50^{\prime} 24.7^{\prime}, \mathrm{N} . \\
17^{\circ} 02^{\prime} 03.6^{\prime}, \mathrm{W}\end{array}$ & \multirow{4}{*}{$\begin{array}{c}\text { Legraa } \\
\& \\
\text { al,2019 }\end{array}$} \\
\hline Etoile Bay & $0,130 \pm 0,070$ & $1,000 \pm 0,400$ & $0,590 \pm 0,007$ & $1,283 \pm 0,04$ & $\begin{array}{c}0,017 \\
\pm 0,002\end{array}$ & $\begin{array}{l}21^{\circ} 02^{\prime} 19.2^{\prime \prime}, \mathrm{N} . \\
17^{\circ} 01^{\prime} 36.8^{\prime}, \mathrm{W}\end{array}$ & \\
\hline Cap Blanc & $0,076 \pm 0,021$ & $0,251 \pm 0,111$ & $0,573 \pm 0.083$ & $1,900 \pm 0,620$ & $\begin{array}{c}0,020 \\
\pm 0,002\end{array}$ & $\begin{array}{l}20^{\circ} 46^{\prime} 47.58^{\prime \prime} \mathrm{N} . \\
17^{\circ} 03^{\prime} 30.24^{\prime \prime} \mathrm{W}\end{array}$ & \\
\hline IMROP & $0,082 \pm 0,012$ & $0,805 \pm 0,028$ & $0,352 \pm 0,008$ & $1.219 \pm 0.424$ & $\begin{array}{c}0,019 \\
\pm 0,002\end{array}$ & $\begin{array}{l}20^{\circ} 51^{\prime}, 26.2^{\prime}, \mathrm{N} . \\
17^{\circ} 01^{\prime}, 52.0^{\prime}, \mathrm{W}\end{array}$ & \\
\hline Iwik & $2,03 \pm 0,32$ & $0,40 \pm 0,09$ & nd & nd & $\begin{array}{c}0,02 \\
\pm 0,002\end{array}$ & $\begin{array}{l}19^{\circ} 53^{\prime} 02.7^{\prime}, \mathrm{N}, \\
16^{\circ} 17^{\prime} 32.8^{\prime}, \mathrm{W}\end{array}$ & \multirow{2}{*}{$\begin{array}{c}\text { S.Bilal, } \\
\text { Thesis } \\
2014\end{array}$} \\
\hline Mamghar & $1,96 \pm 0,36$ & $0,33 \pm 0.6$ & nd & nd & $\begin{array}{c}0,02 \\
\pm 0,002\end{array}$ & $\begin{array}{l}19^{\circ} 52^{\prime} 03.3^{\prime \prime}, \mathrm{N} \\
16^{\circ} 17^{\prime} 43.2^{\prime \prime} \mathrm{W}\end{array}$ & \\
\hline
\end{tabular}


Comparing the concentrations of $\mathrm{Cd}(0.04$ to $0.265 \mathrm{mg} / \mathrm{kg})$ recorded in the present work with those found $(0.076$ to $0.130 \mathrm{mg} / \mathrm{kg}$ ) by Legraa et al. (2019), we found that the cadmium level in Lévrier Bay are increased in recent years. Meanwhile, the cadmium level in Lévrier Bay is less than in Iwik and Mamghar (2.03 and 1.96 respectively. Bilal 2014) at Banc d'Arguin region. The important variation of cadmium level could be linked to the permanent presence of upwelling in this area. However, mercury concentration in Lévrier Bay was low in ours samples. The considerable variation between ours finding and others previous studies. in Mauritania coast (Legraa et al. 2019; Bilal 2014) can probably be linked to the sampling points that differ in this study compared to previous works.

\subsection{Relationship between the trace metals}

Figure 2 shows a relatively high positive correlation between $\mathrm{Zn}$ and $\mathrm{Pb}$ and moderate correlation between zinc, lead and copper, then these correlations indicate a possible common source of the elements from industrial and/or urban activities as well as comparable behavior in the sediment. The percentage of the eigenvalues relative to the variables $\mathrm{Zn}, \mathrm{Cu}$ and $\mathrm{Pb}$ are well projected on Axis1, because it $66.25 \%$ of information. However, Cd is well represented on Axis 2 and constitutes 18,12\% of information; the source of which can be attributed to other origins.

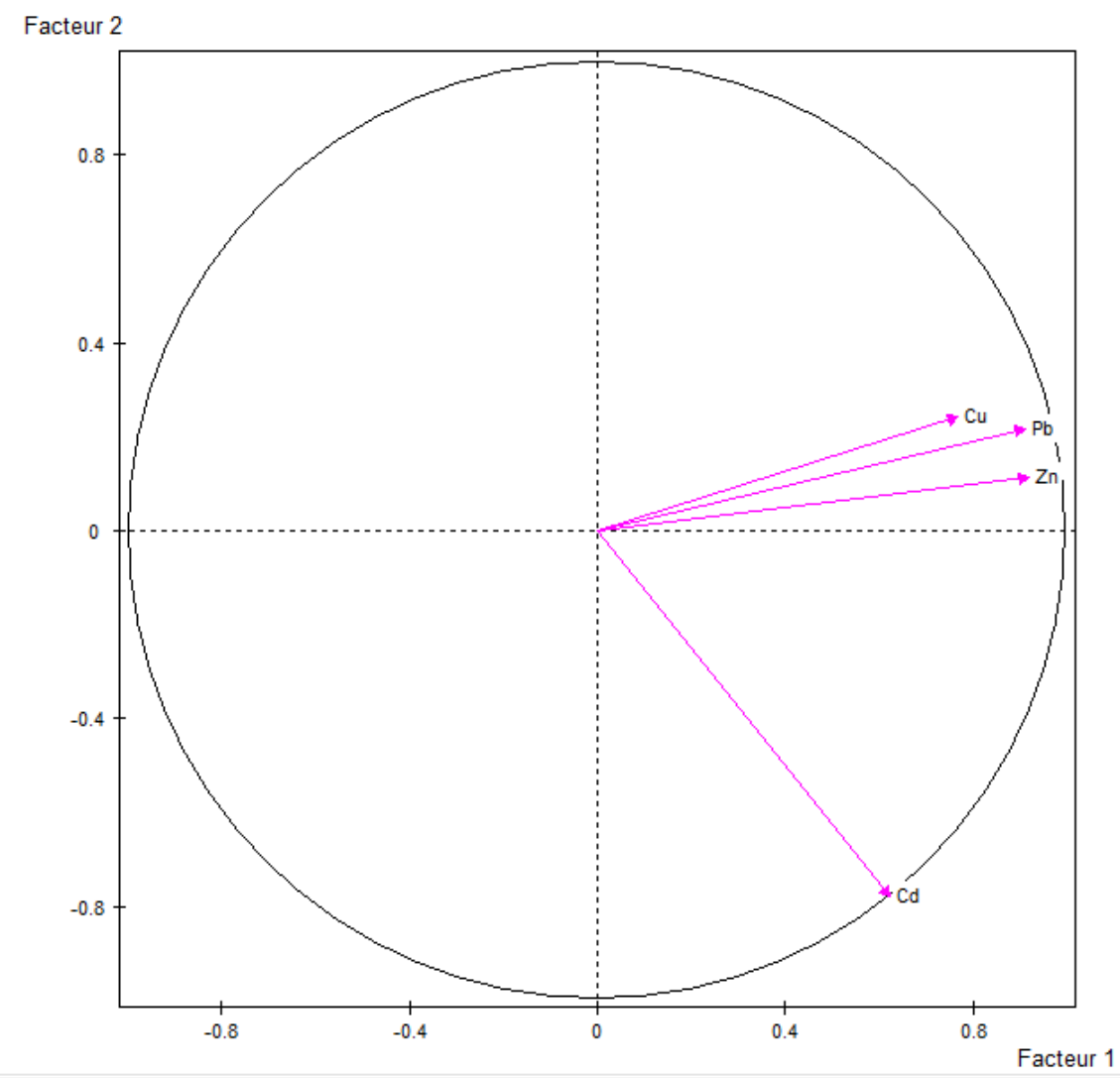

Fig. 2. PCA between the variables (trace metals: $\mathrm{Zn}, \mathrm{Pb}, \mathrm{Cu}$ and $\mathrm{Cd}$ ) in the surface sediments of the Lévrier Bay

\section{2. Seasonal variations}

The ANOVA test showed the absence of significant $(\mathrm{P}>0,5)$ seasonal variations in the metallic elements analyzed in the sediments at all the sites studied (Table 4). 
Table 4.

ANOVA analysis of variance of the elements studied $(\mathrm{ZN}, \mathrm{Pb}, \mathrm{Cu}$ et $\mathrm{Cd})$

\begin{tabular}{|c|c|c|c|c|}
\hline Metal & Cd & Pb & Cu & Zn \\
\hline P. value seasons & 0,219 & 0,076 & 0,217 & 0,123 \\
\hline
\end{tabular}

Although the ANOVA applied between metallic elements, sites and seasons did not give rise to a significant season effect because this statistical analysis used the cumulative average concentrations; nevertheless, in all the sites studied, zinc displayed in hot season its highest contents of all the elements analyzed and its lowest values in cold season (Fig. 3). For the other elements, the highest values were also encountered in the hot season and the lowest values of the metals analyzed were recorded in the cold season for all studied sites, with the exception of $\mathrm{Cd}$, which had its highest content in the cold -hot season. The high concentrations of $\mathrm{Zn}$ observed at PM during the cold season may be due to intensive ore shipping activities during this period.

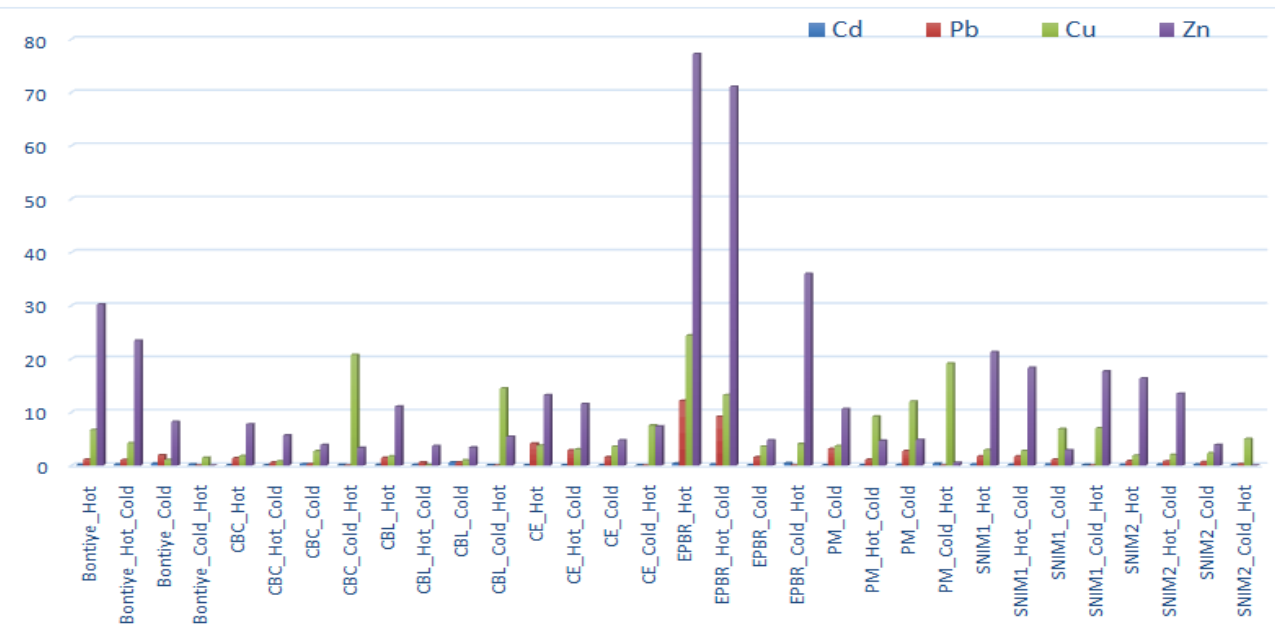

Fig. 3. Variations in trace metals by site and by season.

\subsection{Comparison with previous studies carried out on the Mauritanian coast}

For comparison, the concentrations found for $\mathrm{Pb}, \mathrm{Cu}$ and $\mathrm{Zn}$ in the sampling sites of the present study remain higher than those found by other authors in previous studies carried out on the Mauritanian coast for the same elements (Legraa et al, 2019 ; Bilal, 2014).This may be due to the absence of industries and infrastructures at the sites sampled in previous studies, unlike those in this work, the sediments of which were collected in areas close to industries that could be sources of elements cited. Moreover, the concentrations of $\mathrm{Cd}$ recorded in the present work are similar to those found in the works carried out on the Mauritanian coast, with the exception of certain high contents of this element encountered in Iwik and Mamghar (Banc d'Arguin ), which could be linked to the permanent presence of upwelling in this area.

\subsection{Comparison with international standards}

Spain and France are among the various countries' signatories to the Oslo Convention for the Guide values proposed for trace metals (Alzieu et al. 1999). Environment Canada (CCME, 1999), whose ELP is the concentration above which harmful effects are expected to occur frequently and the ISOGS is a quality guideline value. The comparison between the average concentrations of trace metals in this study and those proposed by the international standards relating to the toxicity of metals in surface sediments showed that all the values recorded for trace metals in all the sites of the present work are less than those recommended by these standards (Table 5). 


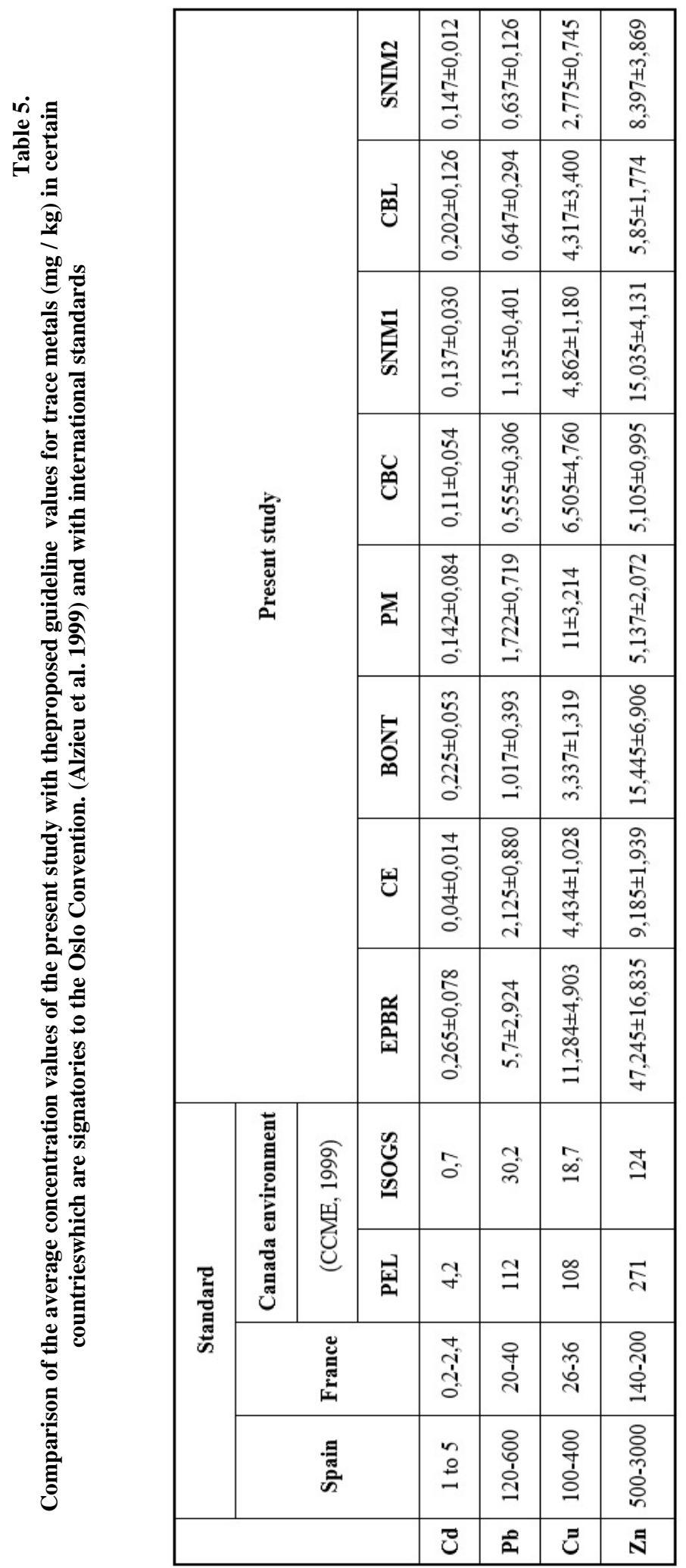




\section{CONCLUSION}

The five metals $(\mathrm{Zn}, \mathrm{Cu}, \mathrm{Pb}, \mathrm{Cd}$ and $\mathrm{Hg}$ ) were detected in our samples and their concentrations in sediment were generally heterogeneous and vary according to the metal analyzed and the sampling site, where $\mathrm{Zn}$ showed the high value recorded among all metallic elements, according to the order $\mathrm{Zn}>\mathrm{Cu}>\mathrm{Pb}>\mathrm{Cd}>\mathrm{Hg}$.

The metallic elements analyzed displayed significant seasonal variations for certain studied sites; however, the use of ANOVA did not show any seasonal effect.

Indeed, the present work shows high average concentrations of the metals studied in the surface sediments than those found for the same metallic elements in recent previous studies at the Lévrier Bay, which due to the absence of important sources in metals at the sampled sites in previous work.

Furthermore, the average concentrations of the metals studied in this work are all below the average values of the international standard guideline relating to the toxicity of surface sediments. However, the high concentrations of metals at the EPBR and BONT sites compared to those found for the same elements at the other sampling sites could be explained, on the one hand, by the increased presence of artisanal canoes and coastal vessels at EPBR level (home port), and by the presence of all fishmeal and fish oil production plants at BONT on the other hand, which discharges may be the source having contributed to the elevation of the trace metals at these two spaces.

\section{ACKNOWLEDGEMENTS}

The authors sincerely thank the University of Nouakchott Al Aasriya (Mauritania), the Mauritanian Institute for Oceanographic and Fisheries Research (IMROP) and the National Office of Sanitary Inspection of Fishery and Aquaculture Products (ONISPA) for their support with regard to the different parts of this work.

\section{R E FER E N C E S}

Alzieu, C. (Ed.) (1999). Dragages et environnement marin : état des connaissances. IFREMER: Plouzané, France, $223 \mathrm{p}$.

Belin, C. \& Le Gal D. (2005). Mission pour l'évaluation du réseau de surveillance sanitaire du milieu marin en Mauritanie et pour l'expertise du système d'analyse des toxines mis en place par l'IMROP. Rapport, IFREMER, $38 \mathrm{p}$.

Bilal, S. (2014). Contribution à l'étude de la qualité des eaux du Banc d'Arguin (Mauritanie) : Dosage des métaux lourds chez le Mollusques (Anadara Senilis), le Poissons Tilapia (Sarotherodon melanotheron) et dans le Sédiment. Thèse de Doctorat. Faculté des Sciences de Kénitra. Université Ben TOFAIL,Maroc, 160p

Bowen, H.J.M. (1966). Trace Elements in Biochemistry. Academic Press, London, 241 p.

Dartige, A.Y. (2006). Teneur en métaux lourds (Cadmium, Zinc, Fer et Cuivre) de la moule Perna perna prélevée dans la Baie du Lévrier (Mauritanie). Thèse, Univ. Libre de Bruxelles (VUB), 120 p.

Dartige, A.Y., \& Ould Dedah, S. (1996). Etat des connaissances sur la pollution marine en Mauritanie. Proceedings of the INOC Workshop, $7 \mathrm{p}$.

Diop, C., Dewaele, D., Diop M et al. (2014). Assessment of contamination, distribution and chemical speciation of trace metals in water column in the Dakar coast and the Saint Louis estuary from Senegal, west Africa. Mar Pollut Bull 86:539-546.

Diop, C., Dewaele, D., Toure, A \& al. (2012). Study of sediment contamination by trace metals at waste water discharge points in Dakar (Senegal). J. Water Sci. 25 (3), 277-285.

Dubrovin B., Mahfoudh, M., \&Dedah, S. (1991). La ZEE Mauritanienne et son environnement géographique et hydroclimatique. Bulletin CNROP, 23, 227p.

Fraga, F. (1973). Oceanografia química de la región de afloramiento del noroeste de Africa .1. Resultados Expediciones Científicasdel Buque Oceanográfico Cornide de Saavedra 2 : 13-52.

IMROP. (2019). Institut Mauritanien de Recherches Océanographiqueset des Pêches ; Rapport de synthèse du Neuvième édition du groupe de travail : "Aménagement des ressources halieutiques et gestion de la biodiversité au service du développement durable ».9 p. 
Kaimoussi, A., Chafik, A., Mouzdahir, A., \& Bakkas, S. (2000). Les métaux lourds dans les sédiments superficiels de la cote littorale de la région d'El Jadida et de l'estuaire d'Oum R'bia (MAROC). bull. Inst. Natn. Scien. Tech. Mer de Salammbô, vol. 27.

Legraa, M. H., Erraoui, H., Dartige, A. Y., et al. (2019). Assessment of metallic contamination of the northen Atlantic coast of Mauritania (Coastal fringe "Lévrier Bay"), using Perna perna. International Journal of Civil Engineering and Technology (IJCIET). Volume 10, Issue, pp. 782-795.

Legraa, M. H., Mohamed Saleck, A., Dartige, A. Y., et al. (2019). Assessment of metal contamination in coastal sediments of the Lévrier Bay area, Atlantic Ocean, Mauritania. GeographiaTechnica, Vol. 14, Issue 1, pp 65 to 81 .

Liang, C.P., Liu, C.W., Jang, C.S., Wang, S.W., Lee, J.J., (2011). Assessing and managing the health risk due to ingestion of inorganic arsenic from fish and shellfish farmed in black foot disease areas for general Taiwanese. J. Hazard. Mater. 186, 622-628.

M'Hamada M., Ould Mohamed Cheikh M., Dartige A., Erraioui H, (2011). Etat de la contamination des côtes atlantiques de Nouadhibou par les métaux lourds (Mauritanie). Conférence Méditerranéenne Côtière et Maritime. EDITION 2, Tanger, Maroc.

Manriquez, M., Fraga, F. (1982). The distribution of water masses in the upwelling region off Northwest Africa in November. Rapp. P.-v. Réun. Cons. int. Explor. Mer, 180. P. 39-47.

Memet, V. (2011). Assessment of heavy metal contamination in sediments of the Tigris River (Turkey) using pollution indices and multivariate statistical techniques. Journal of Hazardous Materials. 195, 355-364.

Odin, M. (1995). Transferts des dérives du mercure et du cadmium entre les sédiments ou la colonne d'eau et les larves d'Hexageniarigida (Ephéméroptères), en fonction des conditions expérimentales (température, photopériode, pH et nature du sédiment). Doc. Univ. Bordeaux I .273 p.

Organisations Liste par pays (Mauritania) : https://webgate.ec.europa.eu/sanco/traces/output/non_eu_listsPerCountry_fr.htm.

Ould Dedah, S. (1993). Wind, surface water temperature, surface salinity and pollution in the area of the Banc d'Arguin, Mauritania. Hydrobiologia 258, 9-19-

Pichard, A., Bisson, M., Houeix, N., \& al. (2005). Fiche de données toxicologiques et environnementales des substances chimiques. INERIS. Cuivre et ses dérivés.66P.

Sidoumou, Z., Romeo, M., Gnassia-Barelli, M., Nguyen, P., Caruba, R. (1992). Détermination de la qualité des eaux du littoral mauritanien par la mesure des métaux traces chez les mollusques Donax rugosus et Venus verrucosa. Hydroécol. Appl., Tome 4, Vol 2, pp 33-41.

UICN/BRAO (2008). Evaluation de l'efficacité de la gestion des Aires protégées : parcs et réserves de Mauritanie.

USEPA. (2002). Methods for Measuring the Acute Toxicity of Effluents and Receiving Waters to Freshwater and Marine Organisms. fifth ed. U.S. Environmental Protection Agency, Office of Water, Washington.

Wagne M.M., Dartige A., Sefrioui S., Zamel M.L., Tounkara H. \& Bah M.L., 2013. Utilisation de la moule Perna perna en biosurveillance du cadmium et du plomb dans les eaux de la baie du Lévrier, Mauritanie. Journal des Sciences Halieutique et Aquatique 7:287-295.

Wagne, M. M., Brahim, H. O., Dartige, A., \& Séfrioui, S. (2011). Contribution à l'étude du phytoplancton potentiellement nuisible de la baie du Lévrier (Mauritanie). Bulletin de l'Institut Scientifique, Rabat, section Sciences de la Vie, $n^{\circ} 33(2)$, p. 31-41.

Zamel, M. L et al. (2010). Suivi de la qualité du milieu marin et identification des sources de pollution des côtes mauritaniennes (Baie du Lévrier et le Sud du Cap Blanc).Tunisian Journal of Medicinal Plants and Natural Product, pp30-36 